\title{
Detection of High-Risk Human Papillomavirus in Cervix Sample in an 11.3-year Follow-Up after Vaccination against HPV 16/18
}

\section{Detecção de papilomavírus humano de alto risco em amostras de colo uterino em 11.3 anos de acompanhamento após vacinação contra HPV 16/18}

\author{
Cirbia Silva Campos Teixeira ${ }^{1} \quad$ Julio Cesar Teixeira ${ }^{1}$ \\ Helymar Costa Machado ${ }^{2}$ Luiz Carlos Zeferino ${ }^{1}$
}

Eliane Regina Zambelli Mesquita Oliveira ${ }^{1}$
Address for correspondence Julio Cesar Teixeira, MD, PhD, Faculdade de Ciências Médicas da Universidade de Campinas (UNICAMP), Centro de Atenção Integral à Saúde da Mulher (CAISM), Rua Alexandre Fleming, 101-Cidade Universitária, Campinas, SP, Brazil 13083-881 (e-mail: juliotex@fcm.unicamp.br; juliotex@uol.com.br).

Rev Bras Ginecol Obstet 2017;39:408-414.

received

November 16, 2016

accepted

April 28, 2017
Purpose the aim of this study was to evaluate the pattern of human papillomavirus (HPV) detection in an 11.3-year post-vaccination period in a cohort of adolescent and young women vaccinated or not against HPV 16/18.

Methods a subset of 91 women from a single center participating in a randomized clinical trial (2001-2010, NCT00689741/00120848/00518336) with HPV 16/18 AS04adjuvanted vaccine was evaluated. All women received three doses of the HPV vaccine $(n=48)$ or a placebo $(n=43)$, and cervical samples were collected at 6 -month intervals. Only in this center, one additional evaluation was performed in 2012. Up to 1,492 cervical samples were tested for HPV-DNA and genotyped with polymerase chain reaction (PCR). The vaccine group characteristics were compared by Chi-square or Fisher exact or Mann-Whitney test. The high-risk (HR)-HPV 6-month-persistent infection rate was calculated. The cumulative infection by HPV group was evaluated by the Kaplan-Meier method and the log-rank test.

Results the cumulative infection with any type of HPV in an 11.3-year period was $67 \%$ in the HPV vaccine group and $72 \%$ in the placebo group $(p=0.408)$. The longitudinal analysis showed an increase of $4 \%$ per year at risk for detection of HR-HPV (non-HPV 16/ 18 ) over time ( $p=0.015)$, unrelated to vaccination. The cumulative infection with HPV $16 / 18$ was $4 \%$ for the HPV vaccine group and $29 \%$ for the placebo group $(p=0.003)$. There were 43 episodes of HR-HPV 6-month persistent infection, unrelated to vaccination. polymerase chain reaction
DOI https://doi.org/

10.1055/s-0037-1604133. ISSN $0100-7203$.
Copyright (e 2017 by Thieme Revinter

Publicações Ltda, Rio de Janeiro, Brazil
License terms

c) $(1) \$$ 


\begin{abstract}
Resumo

\section{Palavras-Chave}

- papilomavírus humano

- colo uterino

- vacinas contra papilomavírus

- vacina contra papilomavírus humano16 e 18 VLPL1

- testes de DNA-HPV

- reação em cadeia da polimerase

Objetivos avaliar o padrão de detecção do papilomavírus humano (HPV) em um período de 11.3 anos após a vacinação em uma coorte de adolescentes e mulheres jovens vacinadas ou não contra HPV 16/18.

Métodos avaliou-se um subgrupo de 91 mulheres de um único centro, participantes de ensaio clínico randomizado (2001-2010, NCT00689741/00120848/00518336) com a vacina contra HPV $16 / 18$ com adjuvante AS04. Todas as mulheres receberam três doses de vacina contra HPV $(n=48)$ ou placebo $(n=43)$, e tiveram amostras cervicais coletadas em intervalos de 6 meses. Somente neste centro, uma avaliação adicional foi realizada em 2012. Um total de 1.492 amostras cervicais foram testadas para DNA-HPV e genotipadas com reação em cadeia da polimerase (RCP). As características dos grupos de vacina contra HPV ou placebo foram comparadas pelo teste de Qui-quadrado ou teste exato de Fisher ou teste de Mann-Whitney. A infecção persistente por 6 meses pelo HPV de alto risco (AR) foi calculada. A infecção cumulativa por grupo foi avaliada pelo método de Kaplan-Meier e pelo teste log-rank.

Resultados a infecção cumulativa com qualquer tipo de HPV em 11.3 anos foi de 67\% no grupo vacina contra HPV e de $72 \%$ no grupo placebo $(p=0,408)$. A análise longitudinal mostrou um aumento de $4 \%$ ao ano no risco de detecção de HR-HPV (não-HPV 16/18) ao longo do tempo $(p=0,015)$, não relacionado com a vacinação. A infecção cumulativa com HPV $16 / 18$ foi de $4 \%$ para o grupo vacina contra HPV e $29 \%$ para o grupo placebo $(p=0,003)$. Houve 43 episódios de infecção persistente por 6 meses por HR-HPV, não relacionados com a vacinação.

Conclusões este estudo mostrou a manutenção da taxa de detecção viral, acumulando testes positivos de HR-HPV (não HPV-16-18) durante longo período pósvacinação, independentemente da vacinação prévia. Isto sinaliza que a alta positividade dos testes de HPV pode ser mantida após a vacinação.
\end{abstract}

Conclusions this study showed the maintenance of viral detection rate accumulating HR-HPV (non-HPV-16-18) positive tests during a long period post-vaccination, regardless of prior vaccination. This signalizes that the high number of HPV-positive tests may be maintained after vaccination.

\section{Introduction}

The etiology of cervical cancer is related to persistent infection with a high-risk human papillomavirus (HR-HPV)., ${ }^{1,2}$ Our knowledge of the relationship between these viral infections and uterine cervical cancer has led to the development of prophylactic vaccines and their licensing for use in 2006. Since then, the use of these vaccines has progressively expanded in population-based programs around the world, and some preliminary results are already available. ${ }^{3-6}$ Presumably, HPV vaccination on a large scale should interfere with the diversity of HPV types distributed in nature, even those unrelated to the HPV vaccine types. ${ }^{7,8}$ A long transitional period is expected and understanding this process is important to define strategies for the detection of women at risk and to screen for precursor lesions in the post-vaccination era. ${ }^{7-11}$ There is evidence that HPV testing may have better performance in a vaccinated population ${ }^{9-11}$ and that it will be more efficient in the future screening of vaccinated women, when compared with cytology. ${ }^{8}$ Our institution in
Campinas, Brazil, has participated in clinical trials of vaccines against HPV since 2000. This study presents an evaluation of a cohort of women vaccinated against HPV $16 / 18$ or with control vaccine in 2001 and followed-up until 2012, describing the pattern of HR-HPV DNA detection in cervical samples over time as a preliminary estimate of the future performance of HPV tests.

\section{Methods}

We analyzed the data from $\sim 91$ women who participated in a phase IIB, multicenter, clinical trial, with the GlaxoSmithKline (GSK) HPV 16/18 AS04-adjuvanted vaccine, as a prospective cohort study. This clinical trial comprised the primary study and two follow-up extension studies, between 2001 and 2010 (NCT 00689741/ 00120848/ 00518336, www.clinicaltrials. gov), with their results already published. ${ }^{12-14}$ In 2001, 98 women started their participation; they were between 15 and 25 years old, reported six or fewer previous sexual partners, and were naive for HR-HPV detectable infection according to 
screening performed 90-105 days before vaccination. Ninetyone of them received three doses of vaccine, given in a randomized double-blind manner, on a 6-month schedule (0/1/6): 48 women received the HPV vaccine against HPV $16 / 18$ and 43 received the placebo $\left(\mathrm{Al}[\mathrm{OH}]_{3}\right)$. They were followed-up until 2010 and cervical samples were collected at intervals of $180 \pm 45$ days, except in 2003

In 2012, 78 women for whom contact information was available were invited to attend an additional evaluation for the present study, and those who received the placebo in 2001 (35 subjects) were offered the opportunity to receive the licensed vaccine against HPV 16/18. Sixty-seven women accepted the invitation and 59 (32 previously vaccinated with the HPV vaccine and 27 with the placebo) agreed to participate in the current study and undergo a gynecological evaluation with cervical samples collection. The gaps in data collection that occurred in years 2003 and 2011 arose because of the time required for regulatory approval of the research, and in 2003, it was aggravated by the wait for the results from the primary multicenter study analysis before we could move forward. In addition, in 2011, there was a period spent to define the crossvaccination feasibility to the placebo recipients because the same vaccine had just been licensed and available for vaccination in Brazil (year 2010), but only for women up to 25 yearsold. As most of the women were older than 25s, a new study had to be designed and submitted for regulatory approval just to provide cross-vaccination.

The cervical samples collected were preserved in PreservCyt (Cytyc Corporation, Boxborough, MA, USA) and tested with $\mathrm{SPF}_{10} \mathrm{LiPA}_{25}$ assay, ${ }^{15}$ a polymerase chain reaction (PCR) genotyping tool for the detection of 25 HPV types (15 HRHPV), performed by a centralized laboratory with careful quality control, between 2001 and 2010. The samples from the last visit, in 2012 , were stored at $-30^{\circ} \mathrm{C}$ until 2014 and tested with the CLART-HPV2 test (Genomica S.A.U., Madrid, Spain), ${ }^{16}$ a PCR genotyping tool that detects 35 HPV types, the same 15 HR-HPV types as SPF 10 LiPA $_{25}$ plus 5 additional oncogenic high-risk types (HR-HPV 26, 53, 73, 82, and 85), totaling 20 HR-HPV types. The CLART-HPV2 tests were performed at a molecular diagnostic laboratory in São Paulo, Brazil, with experience in HPV testing, and, as a quality control of the stored samples, a set of 20 frozen samples and other 20 'fresh' cervical samples were tested in two laboratories, and by three different assays (local innovative prototype assay, Cobas HPV test [Roche Molecular Systems, Inc., Pleasanton, CA, USA] and CLART-HPV2). The results were concordant and storage time until samples analysis was not considered a concern.

The studies (three consecutive phases of a multicenter study in the period of 2001-2010 and the current singlecenter study) followed the regulatory standards of the National Health Council of Brazil ${ }^{17}$ and were approved by the local Ethics Committee. All subjects signed an informed consent form before their participation in each study.

\section{Statistical Analysis}

We compared the groups (HPV vaccine and placebo) in respect to age and potential risk factors associated with the acquisition of HPV infection: new sexual partner reported in the preceding year, previous pregnancy, regular use (continuous use for 3 months or more each year) of hormonal contraceptives or condoms, and smoking (any amount). Information were recorded at four tie points (in years 2001, 2005, 2010, and 2012). The analysis was performed using the chi-squared $\left(x^{2}\right)$, $\mathrm{X}^{2}$ for trend, Fisher's exact, or Mann-Whitney tests. The longitudinal analysis to estimate the cumulative risk of HPV-positive test result in 11.3 years after vaccination was performed using the Kaplan-Meier method and log-rank test. ${ }^{18}$ The HPV types detected were pooled as follows: any HPV, HR-HPV, HR-HPV (non-HPV 16/18) and HPV 16/18. The HR-HPV 6-month-persistent infection (6MPI) was calculated. For statistical analysis, the SAS 9.2 software (SAS Institute Inc., Cary, NC, USA $)^{19}$ was used and p values $<0.05$ were considered significant.

\section{Results}

At study entry, the age range distributions were similar between the groups and there were no significant differences in terms of the risk factors considered associated with HPV acquisition between the vaccination groups (-Table 1). The maximum follow-up time was 135 months.

The cumulative percentages of subjects with HPV infection throughout the 11.3-year study period and pooled in any HPV type or HR-HPV type were $67 \%$ and $60 \%$, respectively, for the HPV vaccine group and 72 and 63\%, respectively, for the placebo group ( $p=0.408$ and $p=0.452$, respectively) (-Table 2). The cumulative infection rate in the 11.3-year period by HR-HPV (non-HPV 16/18) was $57-58 \%$ for both groups $(p=0.652)$ ( - Fig. 1 ), with an increasing trend of $4 \%$ per year $(p=0.015)$.

On the last visit (2012, CLART-HPV2 test), four HR-HPV (non-HPV 16/18) infections were detected in each group; in the HPV vaccine group as a first detection (all four), and in the placebo group, the other four as repeated detections. The HPV types detected in these eight cases by CLART-HPV2 test were types that could be detected by $\mathrm{SPF}_{10} \mathrm{LiPA}_{25}$ test too, reducing possible interference in results due to different assays applied.

As expected, the cumulative infection by HPV 16/18 was $4 \%$ for the HPV vaccine group and $29 \%$ for the placebo group $(p=0.003)$ (-Fig. 2 and - Table 2 ).

We observed 52 episodes of HR-HPV 6MPI in 31 patients throughout the 11.3-year period. The cumulative rate of HRHPV 6MPI detections for the 11.3-year period was 31\% for the HPV vaccine group and $45 \%$ for the placebo group ( $p=0.189$ ) (-Fig. 3). Considering HPV 16/18 6MPI, no event was observed in the HPV vaccine group, whereas six events were recorded in the placebo group. Of these six events, four were related to HPV-16 and two events related to HPV18.

\section{Discussion}

This is a unique long-term HPV study done in the postvaccination era, and it emphasizes that HR-HPV (non-HPV $16 / 18$ ) continues to occur at the same rate in HPV vaccinated 
Table 1 Distribution of the demographic characteristics checked by time point (years 2001, 2005, 2010 and 2012) and by vaccination group

\begin{tabular}{|c|c|c|c|c|c|c|}
\hline \multirow[t]{4}{*}{ Parameter } & \multirow[t]{4}{*}{ Year } & \multicolumn{5}{|c|}{ Number of answer 'Yes' } \\
\hline & & \multirow[t]{3}{*}{ 'Yes'/total } & \multicolumn{4}{|c|}{ Vaccination group } \\
\hline & & & \multicolumn{2}{|c|}{ HPV vaccine } & \multicolumn{2}{|c|}{ Placebo } \\
\hline & & & $n$ & $\%$ & $\mathrm{~N}$ & $\%$ \\
\hline \multirow[t]{4}{*}{ New sexual partner in last year } & 2001 & $11 / 88$ & $5 / 47$ & 10.6 & $6 / 41$ & 14.6 \\
\hline & 2005 & $20 / 78$ & $10 / 42$ & 23.8 & $10 / 36$ & 27.8 \\
\hline & 2010 & $10 / 75$ & $3 / 41$ & 7.3 & $7 / 34$ & 20.6 \\
\hline & 2012 & $5 / 59$ & $3 / 32$ & 9.4 & $2 / 27$ & 7.4 \\
\hline \multirow[t]{4}{*}{ Previous pregnancy reported } & 2001 & $38 / 88$ & $19 / 47$ & 40.4 & $19 / 41$ & 46.3 \\
\hline & 2005 & $33 / 78$ & $18 / 42$ & 42.3 & $15 / 36$ & 41.7 \\
\hline & 2010 & $14 / 75$ & $8 / 41$ & 19.5 & $6 / 34$ & 17.6 \\
\hline & 2012 & $0 / 59$ & $0 / 32$ & & $0 / 27$ & \\
\hline \multirow{4}{*}{$\begin{array}{l}\text { Hormonal contraceptive } \\
\rightarrow \text { regular use* }\end{array}$} & 2001 & $48 / 88$ & 25 & 53.2 & 23 & 56.1 \\
\hline & 2005 & $49 / 78$ & 28 & 66.7 & 21 & 58.3 \\
\hline & 2010 & $42 / 75$ & 23 & 56.1 & 19 & 55.9 \\
\hline & 2012 & $35 / 59$ & 16 & 50.0 & 19 & 70.4 \\
\hline \multirow{4}{*}{$\begin{array}{l}\text { Condom } \\
\rightarrow \text { regular use }\end{array}$} & 2001 & $26 / 88$ & $9 / 47$ & 19.1 & $17 / 41$ & 41.5 \\
\hline & 2005 & $10 / 78$ & $5 / 42$ & 11.9 & $5 / 36$ & 13.9 \\
\hline & 2010 & $6 / 75$ & $4 / 41$ & 9.8 & $2 / 34$ & 5.9 \\
\hline & 2012 & $5 / 59$ & $3 / 32$ & 9.4 & $2 / 27$ & 7.4 \\
\hline \multirow[t]{4}{*}{ Current smoking } & 2001 & $26 / 88$ & 14 & 29.8 & 12 & 29.3 \\
\hline & 2005 & $12 / 78$ & 6 & 14.3 & 6 & 16.7 \\
\hline & 2010 & $14 / 75$ & 9 & 22.0 & 5 & 14.7 \\
\hline & 2012 & $10 / 59$ & 4 & 12.5 & 6 & 22.2 \\
\hline
\end{tabular}

*Regular use indicates having used the method for at least 3 consecutive months in the last 12 months. For each parameter and period: all tests by Chi-square or Fisher exact or Mann-Whitney were $p>0.05$.

Table 2 Cumulative percentage and number of subjects with HPV infection according to HPV group and vaccine received

\begin{tabular}{|c|c|c|c|c|c|c|c|c|c|c|c|c|c|c|c|c|}
\hline \multirow[t]{4}{*}{ Months after dose 1} & \multicolumn{16}{|c|}{ Cumulative percentage and number of subjects by HPV group } \\
\hline & \multicolumn{4}{|c|}{ Any HPV } & \multicolumn{4}{|c|}{ High risk } & \multicolumn{4}{|c|}{$\begin{array}{l}\text { High risk } \\
\text { (non-HPV 16/18) }\end{array}$} & \multicolumn{4}{|c|}{ HPV $16 / 18$} \\
\hline & \multicolumn{2}{|c|}{$\begin{array}{l}\text { HPV } \\
\text { vaccine } \\
(n=48)\end{array}$} & \multicolumn{2}{|c|}{$\begin{array}{l}\text { Placebo } \\
(n=43)\end{array}$} & \multicolumn{2}{|c|}{$\begin{array}{l}\text { HPV } \\
\text { vaccine } \\
(n=48)\end{array}$} & \multicolumn{2}{|c|}{$\begin{array}{l}\text { Placebo } \\
(n=43)\end{array}$} & \multicolumn{2}{|c|}{$\begin{array}{l}\text { HPV } \\
\text { vaccine } \\
(n=48)\end{array}$} & \multicolumn{2}{|c|}{$\begin{array}{l}\text { Placebo } \\
(n=43)\end{array}$} & \multicolumn{2}{|c|}{$\begin{array}{l}\text { HPV } \\
\text { vaccine } \\
(n=48)\end{array}$} & \multicolumn{2}{|c|}{$\begin{array}{l}\text { Placebo } \\
(n=43)\end{array}$} \\
\hline & $\%$ & Subj. & $\%$ & Subj. & $\%$ & Subj. & $\%$ & Subj. & $\%$ & Subj. & $\%$ & Subj. & $\%$ & Subj. & $\%$ & Subj. \\
\hline 12 & 31 & 15 & 35 & 15 & 17 & 8 & 21 & 9 & 13 & 6 & 12 & 5 & 4 & 2 & 9 & 4 \\
\hline 24 & 40 & 19 & 47 & 20 & 25 & 12 & 33 & 14 & 21 & 10 & 23 & 10 & 4 & 2 & 12 & 5 \\
\hline 60 & 51 & 24 & 64 & 27 & 40 & 19 & 54 & 22 & 38 & 18 & 47 & 19 & 4 & 2 & 20 & 8 \\
\hline 120 & 55 & 26 & 69 & 29 & 47 & 22 & 60 & 24 & 45 & 21 & 58 & 23 & 4 & 2 & 26 & 10 \\
\hline 135 & 67 & 30 & 72 & 30 & 60 & 26 & 63 & 25 & 57 & 25 & 58 & 23 & 4 & 2 & 29 & 11 \\
\hline$p^{*}$ & \multicolumn{4}{|c|}{0.408} & \multicolumn{4}{|c|}{0.452} & \multicolumn{4}{|c|}{0.652} & \multicolumn{4}{|c|}{0.003} \\
\hline
\end{tabular}

Abbreviations: HPV, Human Papillomavirus; Subj., subjects.

*Log-rank test. Multiple HPV detection was considered one event by HPV group. 


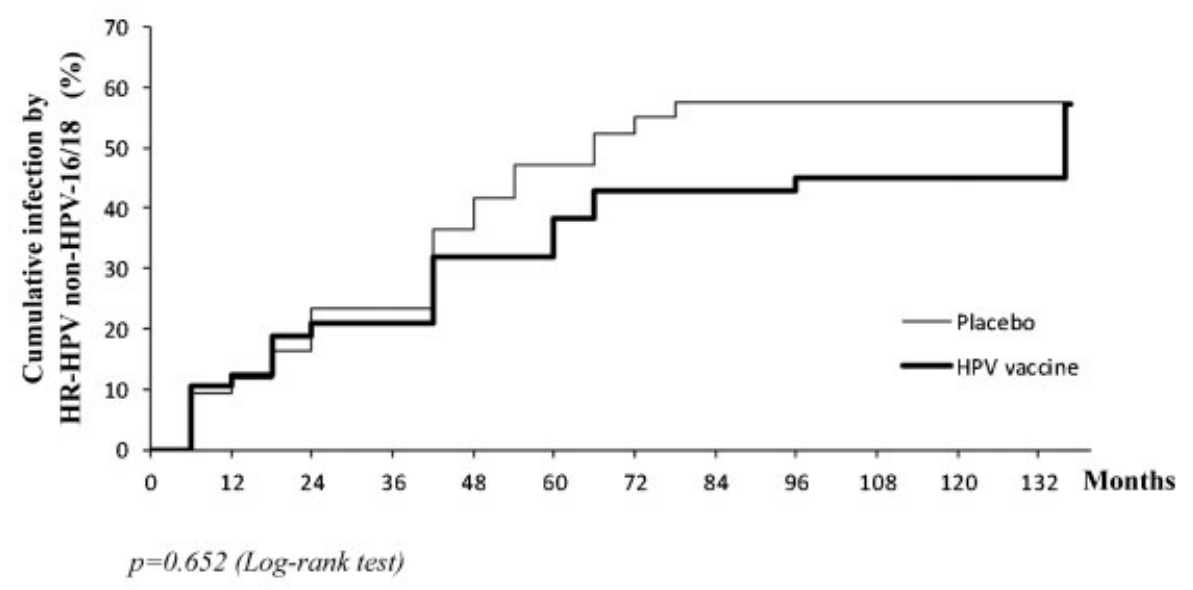

Fig. 1 Cumulative percentage of women with high-risk HPV (non-HPV 16/18) infection detected in long-term follow-up by vaccination group.

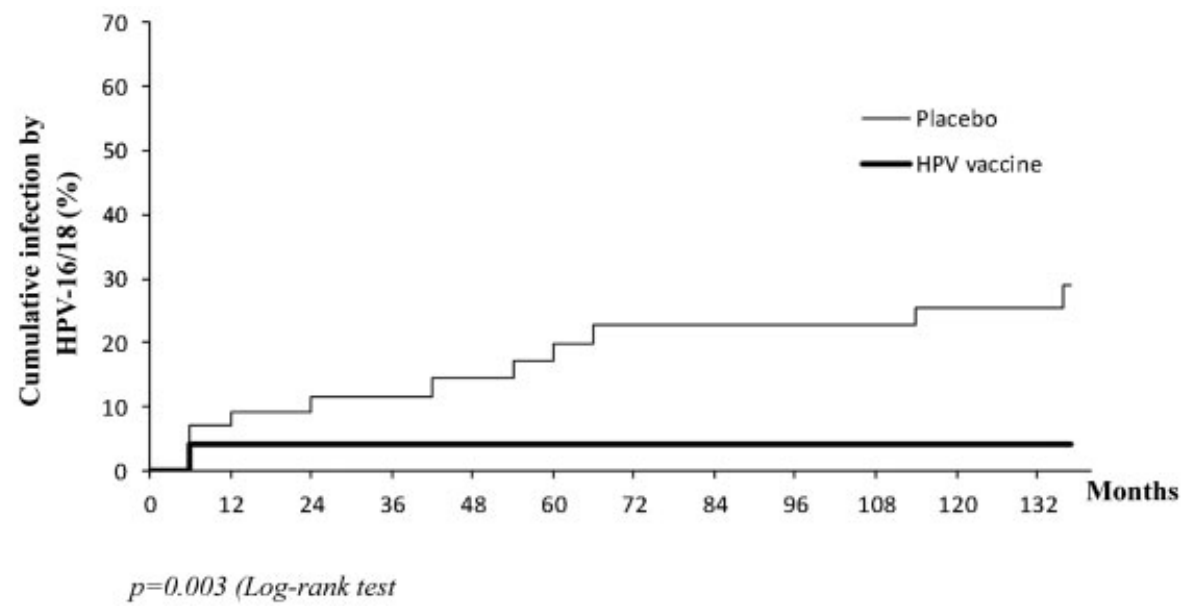

Fig. 2 Cumulative percentage of women with HPV 16/18 infection detected in long-term follow-up by vaccination group.

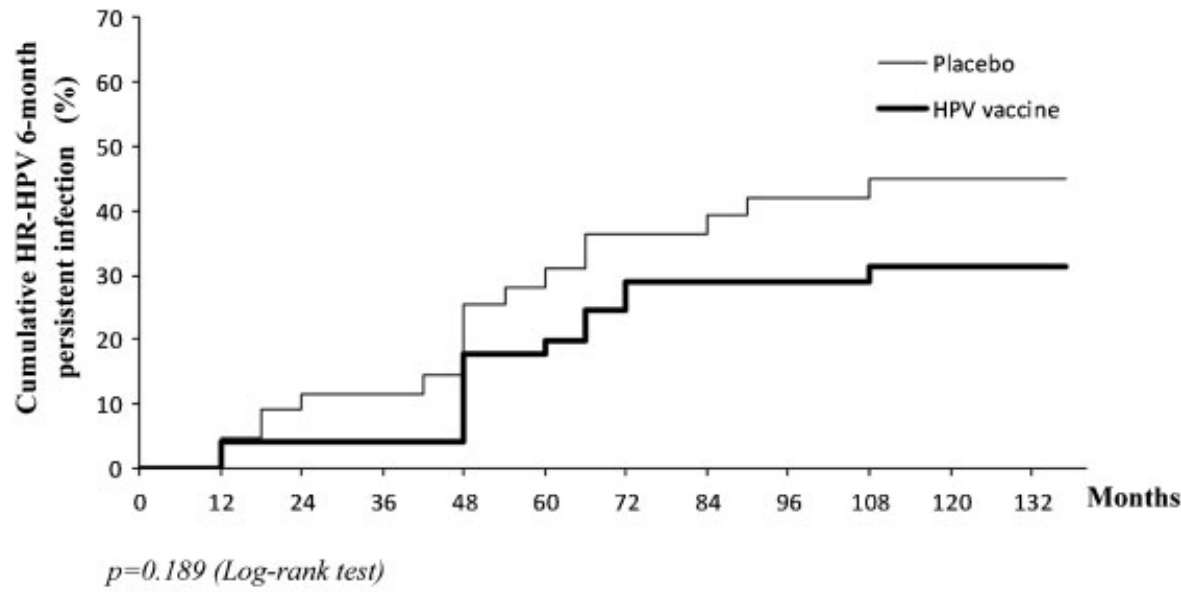

Fig. 3 Cumulative percentage of women with high-risk HPV 6-month persistent infection detected in long-term follow-up by vaccination group. 
group versus unvaccinated women. The cumulative infection rate by any HPV type in 11.3 years after vaccination was significant and unrelated to the vaccine received (67\% in the HPV vaccine group and $72 \%$ in the placebo group). The detection of HR-HPV (non-HPV 16/18) was similar in the 11.3-year post-vaccination period and was not associated with the vaccination received in 2001 , and increasing $4 \%$ per year. As expected, the HPV 16/18 detection rate tended to decrease in the period studied, with a $90 \%$ lower risk of detection if previously vaccinated.

The aim of this study was to assess the long-term pattern of HPV detection, particularly of HR-HPV (non-HPV 16/18), and our results indicate that the previous vaccination against HPV 16/18 was not associated with lower detection rates of HR-HPV (non-HPV 16/18) in this group of 91 women. Our results are in line with the published findings from the major study that analyzed data from all centers and showed an evident vaccine efficacy related to HPV 16/18 detection and no statistic power to show cross-protection against others HR-HPV types. ${ }^{12-14}$

The local cohort studied showed an increase of $4 \%$ per year in the chance of a new HR-HPV detection when samples were taken every 6 months. This finding is consistent with previous observations in the population cohort studied, that the HPV infection remains detectable and with a significant rate of 3 to $7 \%$ for women aged 20 to 44 years (and unvaccinated), as described by Muñoz et al $(2004)^{20}$ for the general population.

The clinical significance of our results can be translated to maintenance of HPV-positive test results even in vaccinated women, with a significant probability to have a positive test result during their regular follow-up. This finding became important once the HPV tests started to be applied for screening. The expectation of improved performance of HPV tests in the future vaccinated population ${ }^{9,10}$ may not happen.

Considering HR-HPV, the persistent infection by the same HPV type detected in 6-month interval showed episodes similarly distributed in both groups (data not shown). Six cases of persistent infection were associated with HPV-16 or -18 and all detected in the placebo group. Additional information about follow-up of these cases: three of these six cases had cytological abnormalities, one had CIN1 and another had CIN2 diagnostic, and all abnormalities were associated with HPV-16. These findings confirm the previously published results for the GSK HPV vaccine trial. ${ }^{12-14}$

This study had some limitations including the small number of cases evaluated and the high frequency (6-month intervals) of sample collection. The strengths were the long follow-up period and the characteristics of the participants who initially were naive for HR-HPV previous detectable infection, randomly vaccinated, placebo controlled and maintained as double-blind, with a good adherence rate (86\%) to the study procedures scheduled up to 2010.

The additional non-randomized, unblinded visit (2012), performed only at our center, made it possible to increase the follow-up time to 11.3 years and reach the number of 1,492 tests evaluated from both groups. It is important to note that were differences related to HPV test assays used in this study.
The CLART-HPV2 test used in the last samples evaluation detected eight cases of HR-HPV (non-HPV 16/18) (four in each vaccine group), the same HPV types already tested by $\mathrm{SPF}_{10} \mathrm{LiPA}_{25}$. The cumulative infection by HR-HPV (non-HPV $16 / 18$ ) showed a final convergence demonstrated by the elevation of the curve for the HPV vaccine group (-Fig. 1). This final pattern of the curve can be explained by the fact that all four cases detected in the HPV vaccine group were new detections, in contrast with the four detections done in placebo group, which happened in patients with previously positive tests, and thus, had no impact on the curve. No additional HPV types were detected. Therefore, we believe that the difference between the HPV test assays did not affect the longitudinal aggregated data and results.

Our results signalize the possibility of maintaining the performance of HPV tests at standard rates, particularly with high positivity rate and limited specificity. These patterns may directly influence the application of the HPV tests in large-scale, particularly in younger women and in the vaccinated population, as discussed in some researches. ${ }^{11,21,22}$ The cohort studied here showed the same pattern with high positivity rate for HPV tests.

In conclusion, in addition to the fact that the prophylactic vaccination provided protection against vaccine-targeted HPV types for up to 11.3 years, the detection of HR-HPV (non-HPV $16 / 18$ ) was maintained for a long period post-vaccination with a slight annual increase of $4 \%$, even in women previously vaccinated, in a well-controlled study. The women vaccinated may remain at the same risk of having an HPV-positive test result in their regular screening and a new approach or screening tests must be defined to find the women who are really at risk.

Financial Support

This study was partially funded by FAEPEX (Unicamp) 519292-1016/13.

Acknowledgments

GlaxoSmithKline provided the data from the Campinas Center for the HPV 16/18 vaccine studies.

\section{References}

1 Walboomers JM, Jacobs MV, Manos MM, et al. Human papillomavirus is a necessary cause of invasive cervical cancer worldwide. J Pathol 1999;189(01):12-19

2 Kjaer SK, van den Brule AJ, Paull G, et al. Type specific persistence of high risk human papillomavirus (HPV) as indicator of high grade cervical squamous intraepithelial lesions in young women: population based prospective follow up study. BMJ 2002;325 (7364):572

3 Tabrizi SN, Brotherton JM, Kaldor JM, et al. Fall in human papillomavirus prevalence following a national vaccination program. J Infect Dis 2012;206(11):1645-1651

4 Markowitz LE, Hariri S, Lin C, et al. Reduction in human papillomavirus (HPV) prevalence among young women following HPV vaccine introduction in the United States, National Health and Nutrition Examination Surveys, 2003-2010. J Infect Dis 2013; 208(03):385-393 
5 Kavanagh K, Pollock KG, Potts A, et al. Introduction and sustained high coverage of the HPV bivalent vaccine leads to a reduction in prevalence of HPV 16/18 and closely related HPV types. Br J Cancer 2014;110(11):2804-2811

6 Mesher D, Panwar K, Thomas SL, Beddows S, Soldan K. Continuing reductions in HPV 16/18 in a population with high coverage of bivalent HPV vaccination in England: an ongoing cross-sectional study. BMJ Open 2016;6(02):e009915

7 Stanley M, Lowy DR, Frazer I. Chapter 12: Prophylactic HPV vaccines: underlying mechanisms. Vaccine 2006;24(Suppl 3): S3, 106-113

8 Markowitz LE, Hariri S, Unger ER, Saraiya M, Datta SD, Dunne EF. Post-licensure monitoring of HPV vaccine in the United States. Vaccine 2010;28(30):4731-4737

9 Stanley M. Human papillomavirus vaccines versus cervical cancer screening. Clin Oncol (R Coll Radiol) 2008;20(06):388-394

10 Ronco G, Dillner J, Elfström KM, et al; International HPV screening working group. Efficacy of HPV-based screening for prevention of invasive cervical cancer: follow-up of four European randomised controlled trials. Lancet 2014;383(9916):524-532

11 El-Zein M, Richardson L, Franco EL. Cervical cancer screening of HPV vaccinated populations: Cytology, molecular testing, both or none. J Clin Virol 2016;76(Suppl 1):S62-S68

12 Harper DM, Franco EL, Wheeler C, et al; GlaxoSmithKline HPV Vaccine Study Group. Efficacy of a bivalent L1 virus-like particle vaccine in prevention of infection with human papillomavirus types 16 and 18 in young women: a randomised controlled trial. Lancet 2004;364(9447):1757-1765

13 Romanowski B, de Borba PC, Naud PS, et al; GlaxoSmithKline Vaccine HPV-007 Study Group. Sustained efficacy and immunogenicity of the human papillomavirus (HPV)-16/18 AS04-adjuvanted vaccine: analysis of a randomised placebo-controlled trial up to 6.4 years. Lancet 2009;374(9706):1975-1985
14 Naud PS, Roteli-Martins CM, De Carvalho NS, et al. Sustained efficacy, immunogenicity, and safety of the HPV-16/18 AS04-adjuvanted vaccine: final analysis of a long-term follow-up study up to 9.4 years post-vaccination. Hum Vaccin Immunother 2014;10(08):2147-2162

15 Quint WG, Scholte G, van Doorn LJ, Kleter B, Smits PH, Lindeman J. Comparative analysis of human papillomavirus infections in cervical scrapes and biopsy specimens by general SPF(10) PCR and HPV genotyping. J Pathol 2001;194(01):51-58

16 Clart Human Papillomavirus 2 [Internet]. Genotyping of human papillomavirus via genomic identification for in vitro diagnosis. 2013 [cited 2015 Feb 6]. Available from: http://genomica.es/en/ documents/CLARTHPV2V10Feb2013English.pdf

17 Brasil. Ministério da Saúde. Conselho Nacional de Saúde. Comissão Nacional de Ética em Pesquisa [Internet]. Resolução $\mathrm{N}^{\circ}$ 196/96 versão 2012. 2012 [citado 2015 Fev 6]. Disponível em: http://conselho.saude.gov.br/web_comissoes/conep/aquivos/resolucoes/23_out_versao_final_196_ENCEP2012.pdf

18 Hand DJ, Crowder MJ. Practical longitudinal data analysis. London: Chapman \& Hall; 1996

19 SAS Institute. The SAS System for Windows (Statistical Analysis System), version 9.2. Cary: SAS Institute Inc; 2002-2008

20 Muñoz N, Méndez F, Posso H, et al; Instituto Nacional de Cancerologia HPV Study Group. Incidence, duration, and determinants of cervical human papillomavirus infection in a cohort of Colombian women with normal cytological results. J Infect Dis 2004;190(12): 2077-2087

21 Arbyn M, Sasieni P, Meijer CJ, Clavel C, Koliopoulos G, Dillner J. Chapter 9: Clinical applications of HPV testing: a summary of meta-analyses. Vaccine 2006;24(Suppl 3):S3, 78-89

22 Hestbech MS, Lynge E, Kragstrup J, Siersma V, Vazquez-Prada Baillet M, Brodersen J. The impact of HPV vaccination on future cervical screening: a simulation study of two birth cohorts in Denmark. BMJ Open 2015;5(08):e007921 